\title{
Tudang Sipulung: A Conflict Resolution Wisdom of Bugis- Makassar Community
}

\author{
Muhammad Syarif Nuh \\ Faculty of Law, Indonesia Muslim University of Makassar \\ Jl. Urip Sumohardjo KM. 5, Panakkukang, Makassar, South Sulawesi 90231, Indonesia \\ Tel./Fax:+62-411-455666 E-mail: muh.syarif2014@gmail.com
}

Submitted: Apr 22, 2016; Reviewed: Jun 5, 2016; Accepted: Jul 12, 2016

\begin{abstract}
This article explores local wisdom "tudang sipulung" (seated together), as conflict settlement medium of Bugis-Makassar Community of South Sulawesi, Indonesia. Tudang sipulung is one of the social institutions that owned the Bugis-Makassar South Sulawesi as a conflict resolution. Tudang sipulung was originally only known in the agricultural community in resolving conflicts related to agriculture, and developing relevant social disputes. Formally, this Tudang Sipulung accommodated by Police in South Sulawesi in the form of a forum called the Mabbulo Sibatang Communication Forum (FKMB) to resolve the conflict. FKMB essence is tudang sipulung between the government, the team of FKMB Police, religious leaders, community leaders, the parties to the dispute and sit together in solving the conflict. Some conflicts that have occurred and are resolved through conflict FKMB PTPN XIV Wajo regency with the community District Kera in Wajo regency, Conflict PTPN XIV Takalar with Gowa regency related to land use and conflict Execution University of Al'As 'yariah Mandar Polewali Mandar, West Sulawesi, Indonesia.
\end{abstract}

Keywords: Bugis-Makassar; Conflict Resolution; Local Wisdom; Tudang Sipulung

DOI: http://dx.doi.org/10.20956/halrev.v1n2.308

\section{INTRODUCTION}

Various social phenomena that emerged lately is quite alarming. The phenomenon of violence in resolving problems become common. The Imposition of policies occurred almost at every level of the institution. Manipulation of information become commonplace. Emphasis and imposition of the will of one group against another group is considered normal. The law is so observant at fault but blind to justice. It seems the character of Indonesian society that is mannered in behavior, consensus in resolving the problem, local wisdom rich plurality, tolerance and mutual cooperation, has been transformed into the hegemony of the new groups that are beating.

Indonesia has a large enough potential conflict that could lead to national integration, which is at the potential conflict between tribes, religion, race, class, regional centers, civil-military, government agencies/ 
countries, Java and non Java-public authorities, etc. another. In addition, there are potential conflicts that characterize the implementation of regional autonomy, such as conflicts between local government (mutual borders), conflicts between locally-based people's power against government officials, conflicts between local government and central government, and so on. ${ }^{1}$

The issue of conflict in Indonesia completion sometimes incomplete. Therefore, addressing a series of conflicts that arise needed the attention of all parties. Various efforts to address the conflict that has been made public and government elite impressed just completing or ending the conflict, has not lead to conflict transformation efforts (conflict transformation) on an ongoing basis. As a result, although the conflict looks stopped but the same potential conflicts that may arise in the future. ${ }^{2}$

Pattern of handling widespread public participation by utilizing local wisdom community conflict resolution is an alternative that should be considered. Through the willingness of the various local actors involved in the conflict and the conflict is expected to utilize local wisdom will be directed into positive energy for the community.

Local wisdom basically provides the cohesive aspects such as adhesive element interfaith, inter citizens, and trust. In this context, local wisdom can be interpreted as a space or arena dialogue to fade any kind of identity politics esklusifitas inherent among various groups. The effort to bridge

\footnotetext{
Agus Supriyanto. (2007). "Local Culture-Based Conflict Resolution", Journal Ibda', 5(2): 1-16.

2 Suprapto. (2013). "Revitalisasi Nilai-nilai Kearifan Lokal Bagi Upaya Resolusi Konflik", Walisongo: Jurnal Penelitian Sosial Keagamaan, 21(1): 19-38.
}

the interests of a broad cross is an effort to build inclusivity in reducing the potential for conflict is greater. ${ }^{3}$

Local wisdom is the potential energy of the system of collective knowledge of the community to live the values that bring the survival of the civilized; live in peace; live in harmony; moral life; live mutual love, grindstones, and parenting; live in diversity; life is full of forgiveness and pengertia;. Jembar tolerant life and heart; living in harmony with the environment; life orientation values that bring on enlightenment; life to resolve problems based on a mosaic of collective reason alone. Wisdom as it grows from deep within its own society. That is the deepest part of the local culture wisdom.

There are six functions of local wisdom, namely (a) as a marker of identity of a community; (b) cross-resident adhesive elements, inter-faith and trust; (c) local wisdom not be forced, but a cultural element that exist and live in the community; (d) local knowledge provide color together for a community; (e) local wisdom will change mindsets and mutual relationship of individuals and groups, to put it above the common ground; and (f) local knowledge can serve to encourage the establishment of togetherness, appreciation as well as a joint mechanism to get rid of the possibility of damaging communal solidarity. ${ }^{4}$

Local wisdom is a miniature grand on the stage of culture, local wisdom is the concept of civility plenary, acting as a beacon

Wasisto Raharjo Jati. (2013). "Kearifan Lokal sebagai Resolusi Konflik Keagamaan", Walisongo: Jurnal Penelitian Sosial Keagamaan, 21(2): 393-416.

4 Alpha Amirrachman (ed.). (2007). Revitalization of Local Wisdom: Study of Conflict Resolution in West Kalimantan, Maluku and Poso. Jakarta: ICIP and Eropean Commission, p. 334-335. 
in every facet of life, to him that, on each of the tribes that inhabit Indonesia, making local wisdom as the cultural richness that must terlestari, a cornerstone in the stand, as well as pride for the community.

Nowadays, the existence of local wisdom, regarded as one of the alternatives in solving a wide variety of deadlock in the settlement of the conflict, both in the local and national scale. Local wisdom can be a solution to the conflict is the wisdom that is suspected to be able to create a cool atmosphere for patterns and interaction between communities. Local wisdom as a glue for a pluralistic society. ${ }^{5}$

The local wisdom approach is very appropriate approach to resolve the conflict because it has been entrenched in the community. ${ }^{6}$ Therefore, local knowledge is something that is already rooted and usually not just a mere profane oriented, but also the sacred oriented so that its implementation can be quickly and easily accepted by the public. With local indigenous conflict resolution is expected to be quickly realized, could be acceptable to all groups so that no hidden latent conflicts in the community. ${ }^{7}$

Local wisdom is the spirit of the people, by Karl Friedrich von Savigny, every nation must be developed based on the typical spirit of the nation (volksgeist). If customary law can be seen as a reflection of the spirit of the

\footnotetext{
Rusli Muhammad. (2012). "Local Wisdom Society Towani Tolotang in Sidenreng Rappang", Journal of Al-Ulum, 12(2): 474-481.

6 Ahsan Yunus, Frans Reumi, \& Irwansyah. (2015). "Recognition of the Customary Court: A Review of Decentralization in Papua as Special Autonomy". Journal of Research in Humanities and Social Science, 3(7), 5769.

7 Ilyas. (2014). "Study of Conflict Resolution InterVillage-Based Local Wisdom in Sigi regency, Central Sulawesi", Journal Academica, 6(1): 12-22.
}

indigenous (volksgeist), should therefore be placed customary law as the basic source of the legal system for custom peoples. ${ }^{8}$

Bugis-Makassar community as well as other ethnic communities have a wealth of cultural values contained in the local wisdom contained in the manuscript Lontara. In this Lontara, Bugis Makassar store of knowledge and wisdom of his past, including a variety of cultural expression. Lontara have an important role in public life Bugis Makassar since ancient times because it contains the values of high culture and the basis grounded in the everyday life of society.

Local wisdom possessed Bugis Makassar is an instrument of civilization, a civilization that has been rooted in a sea of people's lives. In the philosophy of Bugis and Makassar, one of which is known in the local wisdom is tudang sipulung Lontara which is medium in conflict resolution.

\section{ANALYSIS AND DISCUSSION}

Since the first community in South Sulawesi have had to live the principles that serve as a shield to sustain civilized norms has. shield in question are the principles that serve as the motto in protecting the norms of customs as a matter of life in performing all its activities both internally and externally, one of which is tudang sipulung.

Tudang sipulung term is a combination of two words that have significant meaning, which means tudang means sitting and Sipulung means together. So, tudang sipulung means to sit together and come together to discuss various things. Terminological tu-

\footnotetext{
8 Marzali Amri. (2013). "Custom Law, Local Wisdom, and Regional Autonomy in Indonesia”, Southeast Asian Journal of Social and Political Issues, 1(3): 309-315.
} 
dang sipulung on culture Bugis-Makassar (South Sulawesi) literally means "sit together", but conceptually is a space for the public (the people) to voice its interests in finding solutions to the problems faced.

Although tudang sipulung has become part of people's lives Wajo Bugis community in any decision-making since time immemorial, but it is recognized that undiscovered origin of the tudang sipulung. But from Lontara Sukkuna Wajo (LSW) ${ }^{9}$ can be found that tudang sipulung always reflected through the said consultation with the people in any decision-making king (White Matoa). The term tudang sipulung not be separated from the joint conference. Whatever the term of this joint consultation is the result of invaluable historical heritage to be preserved for the people Wajo, the value of which is none other than deliberation and consensus. ${ }^{10}$

At the Bugis-Makassar, in fact, there are some appropriate way to resolve the

Lontara or lontaraq are Bugis palm-leaf manuscript that record knowledge on such topics as history, science, custom, and laws. The term Lontara is derived from the Malay name for palmyra palm, lontar, whose leaves are traditionally used for manuscripts. Lontara' Sukku'na Wajo' is manuscript written by La Sangaji Puanna La Sengneng, Arung Bettempola (of the 18th century). According to Professor Zainal Abidin Farid, the original of this lontara' was composed by the Arung Bettempola at the behest of Arung Matoa La Mappajung Puanna Salowong (1764-1767). All the lontara' available in Wajo at the time were compared, along with hundreds of others from different areas, and the resulting work is now known as the Lontara'na Sukku'na Tana Wajo', or the Complete Chronicles of the Land of Wajo. Succeeding generations added information on to the chronicle bringing the story up to the end of the 19th century. See, Leonard Y. Andaya. (1981). The Heritage of Arung Palakka: A History of South Sulawesi (Celebes) in the Seventeenth Century. The Hague: Nijhoff. [KITLV. Verhandelingen 91, 1981), p 333.

10 Indar Arifin. " Good Governance dan Pembangunan Daerah Dalam Bingkai Nilai Lokal Sebuah Studi Birokrasi dan Perubahan Sosial Politik di Kabupaten Wajo". Available online at: http://repository.unhas. ac.id/bitstream/handle/123456789/2255/Journal-05b. pdf? sequence $=10$ accessed on 26 September 2015 . conflict customary law. Resolves itself, ask a third party as a mediator, and leave it to the authorities (law enforcement/pabbicara). Each of these settlement way has different consequences. The most inexpensive way to resolve conflict is customary or community to resolve themselves by the parties involved in the conflict (by way tudang sipulung followed by tudang pangngadereng). This method is said to be low because it does not require time and cost too much. Condition, each party to the conflict to really understand the nature of the object that is the source of conflict triggers and each party also really intend to create peace together. The problem, often indigenous parties to the conflict, do not understand the nature of the object, so that appears is actually a bout of self-esteem or prestige. If each then persist in prestige and ketidatahuannya, it's become customary conflict is not easily resolved. ${ }^{11}$

If the first way ended deadlocked due to each party persist in prestige and ignorance, can be chosen the second way. Ask for help from a third party (government or other institutions), who is trusted by both sides to find a way out of the circle of indigenous conflict. Third parties who have knowledge and experience as a mediator to solve conflicts, will take some initial steps before providing some alternative solution. Will first explain some termimologi related to the cause of indigenous conflict. After the parties have the same perception about some of the terms that are closely related to the object of the conflict, then given several

\footnotetext{
11 Anonymous, "The concept of Indigenous Conflict Resolution". Available online at: http://telukbone. blogspot.com/2012/12/concept-conflict-settlement-inadat.html accessed on 26 September 2015.
} 
options to solve it. Ultimately determine the choice are parties to the conflict. ${ }^{12}$

Tudang sipulung commonly known in the agricultural world when there is a dispute between farmers. Dispute at farm level usually occurs between farmers and farmer groups or between individual farmers. The dispute could occur because fighting water to irrigate the fields or breach joint decision. Disputes and these violations were given the customary punishment maccera. According to the rules lontarak - customary rules of society Bugis-Makassar written on palm leaves - the level of punishment varies according to the shape of violations, ranging from the supply side dishes, slaughtering chickens, slaughtering goats for salvation, up to expulsion out of the village-the latter rarely done.

Viewed Tudang Sipulung essence, the conception Tudang Sipulung is then considered as a public space otetntik which can mediate the interests of the people and the government (the ruling). A pallontara' (lontara interpreter), Andi Baharuddin describes in the Bugis language that ${ }^{13}$ :

"Naiya riasenge tudang sipulung, iyanaritu mallari ade-e toriolota. Tudang maddepu-deppungeng, tudang mallewo-lewoang nasibawai akkatta maelo sipatangngareng nenniya maelo mala ada assimaturuseng".

"What is meant by tudang sipulung is a tradition that people often do advance (our elders). Sitting together, gathered with the intention of going to deliberation and consensus."

Ibid.

13 Ambo Takko and Mukhlis. (2001). Hak Asasi Manusia dalam Budaya Bugis-Makassar", Research Report. Makassar: UNHAS Research Institute, p. 24.
Exposure above indicate that the tradition tudang sipulung have done long ago by the Bugis Makassar as a shared space for deliberation and agree in the framework of a solution to the problems faced by the community. In any political contest tudang sipulung used as a medium to absorb the aspirations of the people, this forum is not afraid to speak despite the presence of the king (ruler). Communities can speak and express the hope that possessed while providing criticism of the authorities or other institutions. ${ }^{14}$

Decisions is taken in tudang sipulung such, should be based on the principle massolo pao (flowing together), which means that the decision to be reached in the "sit together" (consultation) is a result of the common will and mutual interest, which likened like water flowing together. That is, the will of the ruler (the royal government) and the will of the people must be together in finding common ground based on shared interests. ${ }^{15}$

Tudang sipulung a traditional public space for people to express their aspirations Bugis Makassar to issues of governance, and seek agreement (collective will) to the problems being faced. The community came together to discuss and debate rationally a problem to get a win-win solution, while respecting and upholding the values pangngadereng (customs system). This tudang sipulung be democratic space for the public to obtain said consensus over disputes or problems being faced. If you see tudang sipulung essence, the cultural space tudang sipulung is what can mediate between the interests of the public and the government (authorities),

\footnotetext{
14 R. Siti Zuhro et al. (2011). Wajah Demokrasi Lokal. Jakarta: PT. THC Mandiri, p. 182.

15 Ambo Takko \& Mukhlis, Op.Cit., p. 25
} 
there have been ongoing since the times of the kingdom in South Sulawesi.

All decisions concerning tudang sipulung indigenous issues, should not be changed much less canceled. Joint leader of the people have agreed to make it a permanent decision (ade'). Thus, the customary provisions containing the sanctity, dignity, and sanctity. Changing or perverts means a direct attack on the values that make it up, damaging the common good, despise science, rigging honesty, and destroy the spirit of democracy.

There are five basic into the spirit of tudang sipulung in resolving conflict: First, the value of the base ada tongeng (honest words). This reflects the basic values of conditions that exist in a public space (traditional) should be based on the values of honesty. For example, participants engaged in a Tudang Sipulung to express their views in the form of information or arguments "right (honest)". Information or argument given is not an engineering that hidden behind certain interests, so Tudang Sipulung that goes "too well" to find a solution to a problem for the common good.

Second, the base value lempuk (righteous actions/honest). The basic values associated with the right attitude or action (straight). In this sense, a participant in a discussion does not have the properties and behavior of cheating/ruse. Thus, a public space must be "sterile" of fraudulent, deceptive deceptive, so the conditions that created a fair condition in a Tudang Sipulung.

Third, the base value getteng (cons tancy/firmness). The basic values that third explains that an utterance, gesture, or act must be based (sticking) to the right belief/ objective (values of truth), so that the condition of public spaces created truly reflects the objective conditions (actual), not subjective, impartial or biased.

Fourth, the base value sipakatau (mutual humanizing/respect). The base value has a social dimension that indicates egalitarian interactions in a public space. It shows the relationship of mutual respect and mutual respect between participants in a public space, where each participant has the opportunity/ equal access to the views put forward his views on an issue without force/pressure from any party.

Fifth, the base value mappesona ri pawinruk sewua-E (surrender to the Creator. This value transcendental dimension of religious and cultural activities are guided by any political, which raised keasadaran be "accountability" of each individual to his Creator in any activity of political culture. With awareness of the vertical, the communication that occurs in a public space will always be based on the values of honesty and truth.

Tudang sipulung which is usually followed by a meal together (manre sipulung), as a form of local participation in decision making in the field. This means Tudang Sipulung that models is one of the most important legacy of the understanding of the negotiations to make decisions in various fields. This tudang sipulung is one of the essences of conflict resolution are packed in Mabbulo Sibatang Communication Forum (FKMB) was initiated by South Sulawesi Police Chief, Inspector General of Police. Drs. H. Mudji Waluyo in 2012. 
The terminology of mabbulo sibatang (abbulo sibatang: Makassar), Bulo means bamboo and mabbulo sibatang means bringing together some bamboo sticks into a bond in order to become stron ger and more useful. Ma'bulo Sibatang (gathered together in a bamboo hut $)^{16}$, Like bamboo rafts and bridges, would mean if the bamboo stick used grebes rods and boat crossing. Is not tied to a bamboo bridge grebes neat if used will be stronger and safer, as well as the bond that is formed into a bamboo raft will bring more benefit

Standard Operating Procedure (SOP) FKMB in South Sulawesi Regional Police, stated that the essence Mabbulo Sibatang is one of the principles of community life and local wisdom Bugis-Makassar. Mabulo Sibatang identity as meaningful as "unified commitment" to each other mutual assistance with the principle: rebba sipatokkong (mutually enforce), mali siparappe (to help each other so as not to drift), and malilu sipakainge (reminding each other in the direction of virtue).

The task of Mabbulo Sibatang Communication Forum are:

a. Facilitate and mediate the entire community in resolving problems;

b. Facilitate and mediate the entire community related issues that stand out in a society that requires the completion of a comprehensive manner;

c. Looking for the roots of the problems that arise related to security and order;

d. Finding solutions in settlement issues;

16 Muslimin Machmud. (2013). "Heritage Media and Local Wisdom of Indonesian Society", Global Journal of Human Social Science Arts \& Humanities, 13(6): 5766. e. Communicating and coordinating the components of the public regarding the results of the implementation of activities;

There are at least four-way conflict resolutions in FKMB, the first, as a means of finding a solution to a problem that occurs in order to avoid bias that could tarnish the course of the democratic process. The second, the candidate and his campaign team can communicate and silaturrahim to prevent acts of anarchy. The candidates and their supporters have the same responsibility for the destructive behavior that can be detrimental to the candidate concerned. The third, bringing together opinion (masseddi ada '), brings together attitudes and actions (masseddi gau') of all components of society. Here need the active participation of the community through consultation to solve its own problems found in the election. The fourth, communication is not only in times of conflict, but also the approach to the whole stakehoders election to prevent conflict. Approach Mabbulo Sibatang Communications Forum is non-formal and the level of "preemptive" issues related to security and public as well as the settlement of the problem through consultation (tudang sipulung). ${ }^{17}$

Social conflict resolution is done with tudang sipulung model through FKMB is a land dispute between PTPN XIV at Wajo District with the Kera Distric community who agreed to terms, where the settlement of social conflicts are adopting local cultural wisdom is to use the model mabbulo sibatang that is to sit together to look for solutions to

17 Marwan Mas. "Mabbulo Sibatang dalam Pemilihan Umum", Tribun Timur, December 3, 2012. 
the problems that occur, for example, issues of social conflicts related to land disputes which occurred in the District Keera. Mabbulo sibatang model very effective in solving these problems so the problems are even worse does not happen. ${ }^{18}$ Other conflicts are handled through Mabbulo Sibatang South Sulawesi Police are PTPN XIV Takalar conflict with Gowa regency related to land use; and conflict Execution Al'As'yariah University Mandar (Unasman) Polewali Mandar, West Sulawesi.

Tudang sipulung utilization of traditional institutions, such as FKMB is typical deliberation South Sulawesi, suggests the use of traditional ceremonies for maintaining social integration in the structural-functional, namely social integration between the government and the people and social integration among individuals. ${ }^{19}$

Result of Indar Arifin research, proved that there is value/tradition is attached to this tudang sipulung models make this process goes to the model arbirtase accommodation. That is, that the process tudang sipulung is an imbalance mechanism that accommodates the interests of various parties. Accommodation which takes place is not the accommodation compulsion (coersy), but the accommodations were seen to be interpreted as a model of accommodation arbitration (accommodation which is more kom-

18 Anonymous, Police Headquarters Police Chief Sulsel Terkait Appreciation Against Conflict Resolution of Land Disputes PTPN XIV and Society Wajo, http://m. beritakotaonline.com/5646/mabes-polri-apresiasiterhadap-kapolda-sulsel/ accessed on September 26, 2015.

19 Alham Syahruna R. et al., (2014). "The Role of Culture Tudang Sipulung/Mappalili and Factors Influencing Shifting Cultural Values Farming in South Sulawesi", Socio Humanika: Journal of Humanities and Social Science Education, 7(2): 237-243. promise), mediation (accommodation more tend mediate, bridging, and facilitates), or even be tolerantion (form of accommodation without formal agreements). Almost all values in tudang sipulung prefers synergistic kinship.

\section{CONCLUSION}

Tudang sipulung is one of the social institutions that owned the Bugis-Makassar South Sulawesi in peneyelesian conflict. Tudang sipulung was originally only known in the agricultural community in resolving conflicts related to agriculture, and developing relevant social disputes. Formally, this Tudang Sipulung accommodated by Police in South Sulawesi in the form of a forum called the Mabbulo Sibatang Communication Forum (FKMB) to resolve the conflict. FKMB essence is tudang sipulung between the government, the team of FKMB Police, religious leaders, community leaders, the parties to the dispute and sit together in solving the conflict. Some conflicts that have occurred and are resolved through conflict FKMB PTPN XIV Wajo regency with the community District Kera in Wajo regency, Conflict PTPN XIV Takalar with Gowa regency related to land use and conflict Execution University of Al'As'yariah Mandar Polewali Mandar, West Sulawesi, Indonesia.

\section{BIBLIOGRAPHY}

Agus Supriyanto. (2007). "Local CultureBased Conflict Resolution", Journal Ibda ', 5(2): 1-16.

Ahsan Yunus, Frans Reumi and Irwansyah. (2015). "Recognition of the Customary 
Court: A Review of Decentralization in Papua as Special Autonomy". Journal of Research in Humanities and Social Science, 3(7), 57-69.

Alham Syahruna R. et al., (2014). "The Role of Culture Tudang Sipulung/Mappalili and Factors Influencing Shifting Cultural Values Farming in South Sulawesi", Socio Humanika: Journal of Humanities and Social Science Education, 7(2): 237-243.

Alpha Amirrachman (ed.). (2007). Revitalization of Local Wisdom: Study of Conflict Resolution in West Kalimantan, Maluku and Poso. Jakarta: ICIP and Eropean Commission.

Ambo Takko and Mukhlis. (2001). Hak Asasi Manusia dalam Budaya BugisMakassar", Research Report. Makassar: Unhas Research Institute.

Anonymous, "The concept of Indigenous Conflict Resolution" http://telukbone. blogspot.com/2012/12/concept-conflict-settlement-in-adat.html accessed on 26 September 2015.

Anonymous, Police Headquarters Police Chief Sulsel Terkait Appreciation Against Conflict Resolution of Land Disputes PTPN XIV and Society Wajo, http://m.beritakotaonline.com/5646/ mabes-polri-apresiasi-terhadap-kapolda-sulsel/ accessed on September 26, 2015.

Ilyas. (2014). "Study of Conflict Resolution Inter-Village-Based Local Wisdom in Sigi regency, Central Sulawesi”, Journal Academica, 6(1): 12-22.

Indar Arifin. " Good Governance dan Pembangunan Daerah Dalam Bingkai
Nilai Lokal Sebuah Studi Birokrasi dan Perubahan Sosial Politik di Kabupaten Wajo". Available online at: http://repository.unhas.ac.id/bitstream/ handle/123456789/2255/Journal-05b. pdf?sequence $=10$ accessed on 26 September 2015.

Leonard Y. Andaya. (1981). The Heritage of Arung Palakka: A History of South Sulawesi (Celebes) in the Seventeenth Century. The Hague: Nijhoff.

Marwan Mas. "Mabbulo Sibatang dalam Pemilihan Umum", Tribun Timur, December 3, 2012.

Marzali Amri. (2013). "Custom Law, Local Wisdom, and Regional Autonomy in Indonesia", Southeast Asian Journal of Social and Political Issues, 1(3): 309315.

Muslimin Machmud. (2013). "Heritage Media and Local Wisdom of Indonesian Society", Global Journal of Human Social Science Arts \& Humanities, 13(6): 57-66.

R. Siti Zuhro et al. (2011). Wajah Demokrasi Lokal. Jakarta: PT. THC Mandiri.

Rusli Muhammad. (2012). "Local Wisdom Society Towani Tolotang in Sidenreng Rappang", Journal of Al-Ulum, 12(2): 474-481.

Suprapto. (2013). "Revitalisasi Nilai-nilai Kearifan Lokal Bagi Upaya Resolusi Konflik", Walisongo: Jurnal Penelitian Sosial Keagamaan, 21(1): 19-38.

Wasisto Raharjo Jati. (2013). "Kearifan Lokal sebagai Resolusi Konflik Keagamaan", Walisongo: Jurnal Penelitian Sosial Keagamaan, 21(2): 393416. 